\title{
Health, work ability and work motivation: determinants of labour market exit among German employees born in 1959 and 1965
}

\author{
Anita Tisch
}

Published online: 4 August 2015

(C) Institut für Arbeitsmarkt- und Berufsforschung 2015

\begin{abstract}
In Germany, 20\% of annual retirees withdraw from the labour market early due to work disability. Meanwhile, it has been argued that in modern societies, not only health but also work motivation and self-perceived work ability have growing influences on individual immediate employment decisions. Moreover, work motivation and work ability have been argued to mediate the relationship between health and labour market exit.

Therefore, this article analyses the mediational effect of work ability and work motivation in the relationship between health and labour market exit. The study employs data from the lidA Cohort Study (German Cohort Study on Work, Age, Health, and Work Participation) $(n=3796)$, which is linked to register data from the Federal Employment Agency. The data linkage facilitates following the survey participants' work trajectories even after their interviews and allows for a one-year follow-up study. The sample of the lidA study comprises two cohorts of the ageing German baby boom generation (employees born in 1959 and 1965). The baby boomers are chosen because they are the first cohorts whose official retirement age has been raised to 67 years of age and for whom almost no possibilities of early retirement are available aside from disability pensions.

This article reveals an increased probability of labour market withdrawal within one year after individuals report health impairments, low physical or mental work ability, or a preference for exiting employment (low work motivation). The findings further show that low work motivation
\end{abstract}

\footnotetext{
A. Tisch $(\bowtie)$

Institute for Employment Research,

Regensburger Str. 104,

90478 Nuremberg, Germany

e-mail: anita.tisch@iab.de
}

and low self-perceived work ability can only partly mediate the relationship between impaired health and labour market withdrawal $(<10 \%)$.

Keywords Baby boomers · Health · Labour market participation $\cdot$ Work ability $\cdot$ Work motivation

JEL classification $\mathrm{I} 14 \cdot \mathrm{J} 6 \cdot \mathrm{Z} 130$

\section{Gesundheit, Arbeitsfähigkeit und Arbeitsmotivation: Beweggründe für den Erwerbsausstieg am Beispiel Erwerbstätiger der Geburtskohorten 1959 und 1965}

Zusammenfassung Derzeit sind rund 20\% der jährlichen Rentenneuzugänge in Deutschland vorzeitige Renteneintritte aufgrund von Erwerbsunfähigkeit und damit auf gesundheitliche Einschränkungen zurückzuführen. Gleichzeitig wird argumentiert, dass Gesundheit heute nur noch eine mittelbare Einflussgröße für den Erwerbsausstieg darstellt und dass Erwerbsausstiegsprozesse zunehmend durch Arbeitsfähigkeit und Arbeitsmotivation erklärt werden können.

Der vorliegende Beitrag beschäftigt sich daher mit der Frage, inwiefern selbsteingeschätzte Arbeitsfähigkeit und individuelle Arbeitsmotivation als Mediatoren für den $\mathrm{Zu}$ sammenhang zwischen Gesundheit und Erwerbsausstieg gelten können. Die Studie stützt sich auf Daten der lidAStudie, eine deutsche Kohortenstudie zu Arbeit, Alter, Gesundheit und Erwerbsteilhabe $(n=3.796)$. Um die Erwerbsteilhabe ein Jahr nach der Befragung untersuchen zu können, werden die Befragungsdaten mit prozessproduzierten Registerdaten der Bundesagentur für Arbeit verknüpft, die den individuellen Arbeitsmarktstatus (beschäftigt, arbeitslos, Leistungsbezug) tagesgenau abbilden. Die lidA-Studie 
umfasst zwei Kohorten der Babyboomerjahrgänge: Erwerbstätige, die 1959 und 1965 geboren sind. Die Babyboomer sind aus zwei Gründen besonders interessant für die Analyse von vorzeitigen Erwerbsausstiegsprozessen: Zum einen sind sie die ersten deren offizielles Rentenalter auf 67 Jahre angehoben wurde. Zum anderen haben sie, im Gegensatz zu vorangegangenen Geburtsjahrgängen, neben den Erwerbsunfähigkeitsrenten nahezu keine Möglichkeiten des vorzeitigen Erwerbsausstieges mehr.

Dieser Artikel zeigt im Ergebnis, dass Personen mit gesundheitlichen Beeinträchtigungen, niedrigerer körperlicher oder geistiger Arbeitsfähigkeit sowie Personen welchen eine geringe Arbeitsmotivation zugeschrieben werden kann, eine erhöhte Wahrscheinlichkeit haben aus der aktuellen Beschäftigung auszuscheiden. Die Ergebnisse zeigen aber auch, dass Arbeitsmotivation und Selbsteinschätzung der Arbeitsfähigkeit die Beziehung zwischen Gesundheit und Arbeitsmarktrückzug nur teilweise zu vermitteln vermögen $(<10 \%)$.

Schlüsselwörter Arbeitsfähigkeit · Arbeitsmotivation · Babyboomer · Erwerbsbeteiligung · Gesundheit

\section{Introduction}

In most European welfare states, early retirement programmes were popular from the 1970s until approximately 2000, and most men and women withdrew from employment well before the official retirement age. However, more recent national policies have been influenced by the European Employment Strategy and force older workers to remain in the labour market longer (Annesley 2007). In Germany, these policies, together with growing employment participation by women, have resulted in continuously rising labour market participation rates of workers aged 50 years and older. Meanwhile, early retirement appears to persist: Currently, a significant number, approximately $20 \%$, of annual retirees make use of disability pensions to withdraw from employment (Deutsche Rentenversicherung 2013). Individual retirement decisions mirror institutional retirement pathways (Fasang 2010) and personal preferences and agencies (Higgs et al. 2003). Early retirement therefore is a result of individual preferences as well as legal frameworks.

For the baby boomers ${ }^{1}$, as the next generation of pensioners in Germany, most institutional retirement pathways have been closed. Early retirement, especially before the age of 60 , is only possible due to work disability and the allowance

\footnotetext{
${ }^{1}$ In Germany, the baby boom generation comprises cohorts born in the mid-1950s to the mid-1960s, when the total fertility rate exceeded the reproduction level of 2.1 and more than 1 million babies were born per year.
}

of disability pensions. However, the allowance of disability pensions is subject to rigorous examination, and only individuals with serious health concerns are considered. A great number of individuals consider withdrawal from employment due to individual health impairments without pension payments.

Research indicates that early retirement is closely associated with health and that impaired physical or mental health is the main reason for early labour market withdrawal (Cai and Kalb 2006; van den Berg et al. 2010b; Siegrist et al. 2006). However, work motivation and individuals' perceptions of their physical and mental work ability have also been argued to influence employment decisions (Taylor and Shore 1995; van Dam et al. 2009; Tuomi et al. 2001). In this sense, Peter and Hasselhorn (2013) even argue that in modern societies, poor health may no longer directly influence labour market exit because occupational health and safety measures, compensating technical aids and organisational arrangements might help include people with health-related impairments in the labour market. Rather, the perception of whether one is able to perform the required tasks in a particular workplace (self-perceived work ability) and is willing to participate in the labour market (work motivation) should have a direct influence on the immediate decision to exit employment.

To promote work participation for those at advanced working age, disentangling health from the perception of work ability and preference for work appears necessary (Chirikos 1993). Therefore, this study asks how selfperceived work ability and work motivation mediate the relationship between health and labour market exit. Better knowledge of the associations among health, work ability and work motivation and the influence of these issues on actual labour market participation for those of advanced working age will allow policy makers and human resources managers to support longer employment of older workers.

Several studies have examined the association between health and labour market participation (see e.g. van den Berg et al. 2010b; Bound et al. 1999; Alavinia and Burdorf 2008), and other studies have considered the influence of health and working conditions on work ability and work motivation (Siegrist et al. 2006; Wahrendorf et al. 2013). The interdependent influences of health, work ability and work motivation on actual labour market participation among ageing employees have not been the focus of previous research.

Additionally, previous approaches studying health, work ability or work motivation of older workers concentrate on individuals close to retirement age. However, I argue that today's older workers are very heterogeneous, particularly in terms of their labour market experience and educational background. Cohorts close to retirement show lower average levels of education and more stable employment tra- 
jectories than those currently reaching higher working age. Therefore, different age cohorts within the group of older workers should be analysed independently. This study concentrates on two cohorts born within the German baby boom (in 1959 and 1965) for at least two reasons: First, by the time of retirement, the baby boomers will dramatically increase the old age dependency ratio and challenge the social security systems, such as the pension system or health care system. Therefore, the state has a particular interest in encouraging these cohorts to abstain from early retirement. In fact, the baby boomers are the first cohort whose official retirement age has been raised to 67 . Second, the baby boom cohorts are currently too young for institutional pathways to early retirement other than disability pensions. While many of the older cohorts had the opportunity to retire early, most institutional pathways to early retirement are closed for the baby boom cohorts (Buchholz et al. 2013; Ebbinghaus and Hofäcker 2013). As in many other modern societies, the "early exit trend" is no longer sustainable in Germany (Stattin 2005), and individuals are expected to continue working until they reach the official retirement age. Therefore, labour market exit due to institutional retirement incentives is currently almost impossible among the ageing baby boom cohorts, and policies encouraging employees to remain in the labour market target the baby boomers in particular. In the following section, I review the debate on health, work ability, work motivation and labour market withdrawal at advanced working age before discussing relevant theoretical considerations in Section Three. In Section Four, the hypotheses tested in this approach are summarised. Section Five introduces the data used and the methods applied. Section Six summarises the results, and Section Seven concludes the study by discussing the findings.

\section{A review of health, work ability, work motivation and labour market exit at advanced working age}

\subsection{Health and early withdrawal from the labour market}

Poor health increases the likelihood of labour market exit. Many previous studies on the influence of health on labour market participation have indicated that good health has a positive effect on labour market participation and that poor health increases the probability of labour market exit across all age groups (see e.g. McDonough and Amick 2001; Garcia-Gomez et al. 2010; Cai 2010; Cai and Kalb 2006; Cardano et al. 2004; Suadicani et al. 2013). Although evidence has suggested that health problems do not influence changes in occupational class, impaired health increases the probability of employment exit and decreases the probability of return to the labour market (van de Mheen et al. 1999).
Evidence from previous studies, particularly those focused on older workers, indicates an even stronger association between poor health and labour market exit from paid employment at advanced working age. Older workers are more likely to report poor health than younger workers, and poor health is strongly associated with being unemployed, retired or a homemaker at advanced working age (Alavinia and Burdorf 2008); additionally, health predicts exit from and entry into the labour market (Schuring et al. 2007; Elstad and Krokstad 2003). Regarding early retirement, "health shocks" were found to predict individual retirement behaviour (Disney et al. 2006). From a longitudinal perspective, poor health (van den Berg et al. 2010b; Maurer et al. 2011) and declines in health (Bound et al. 1999) have been found to influence exit from paid employment among older workers. Moreover, Avendano and Mackenbach (2010) revealed that long-term illness was associated with early exit from the labour market.

\subsection{Self-perceived work ability and early withdrawal from} the labour market

The concept of work ability was established in the early 1980 s as an index of the ability of a employee to meet his or her job demands. It describes a personal judgement of one's own capability to perform paid work. Interest in work ability reflected the beginning of an European trend towards early retirement, which raised the question how long workers feel capable of working with respect to current and future job demands and their perceptions of individual health resources (Ilmarinen and Tuomi 1993; Ilmarinen 1999). Ilmarinen (2001) demonstrated that the perception of work ability often reaches its peak before age 50 and, on average, declines afterwards, particularly among those in physically or mentally demanding positions.

With a decline in the perception of one's capability to perform work-related tasks, the likelihood of absence due to illness and employment exit increases. For a large sample of Dutch construction workers, Alavinia et al. (2009) found that self-perceived work ability was a predictor of absence due to illness, and Reiso et al. (2001) revealed that reduced scores of self-perceived work ability were associated with longer absences due to illness. With respect to early exit from working life, a study of professional cleaners indicated that lower levels of work ability predicted employment withdrawal (Hopsu et al. 2005). Moreover, a representative study of wage earners in Denmark based on survey data linked with a register of social payment transfers indicated that a decrease in perceived work ability was associated with an increased risk of early retirement (Sell 2009). 
2.3 Work motivation and early withdrawal from the labour market

While self-perceived work ability already includes a judgement of one's own physical and mental capability, individual preferences for paid work are a more general measurement of the motivation to work. Studies indicate that job satisfaction (Topa et al. 2009) and retirement intentions are strong predictors of actual retirement behaviour (Henkens and Tazelaar 1994; Prothero and Beach 1984; Örestig et al. 2013). However, the motivation to work at advanced working age depends on not only retirement intentions but also particular job assignments, satisfaction with an employer and the general demands of the current labour market (Suadicani et al. 2013). Therefore, the motivation to work declines with physically demanding tasks, stress in the workplace and a poor psychosocial work environment (Wahrendorf et al. 2013) or when employment prospects are poor (Houston and Lindsay 2013).

\subsection{Interrelations between health and work ability and health and work motivation}

Nilsson et al. (2011) demonstrated that health is associated with both the "can work" and the "want to work" attitudes. In accordance with their findings, several recent studies indicated an association between poor health and low selfperceived work ability (Ilmarinen et al. 2005; Sörensen 2008). Poor health, particularly in addition to ageing, is strongly associated with work ability among a variety of different socio-economic groups. Accordingly, work ability and health are closely related in both white-collar and bluecollar workers. Studying professionals, van den Berg et al. (2008) found that mental and physical health are important to self-perceived work ability. Alavinia et al. (2007) similarly found that workload and work-related risk factors for health predict declining work ability among construction workers. While Alavinia et al. (2007) restricted their analysis to male workers, Gamperiene et al. (2008) demonstrated that reduced work ability is also strongly associated with physical and mental health among women. However, work environment appears to be of minor importance for female workers.

With regard to the association between the motivation to work and health among adult workers, most studies concentrate on the relationship between health and the willingness to work until the official retirement age. These studies typically indicate that poor health encourages early retirement (Heponiemi 2008; Harkonmäki et al. 2006; van den Berg et al. 2010a), increases older workers' intention to exit the labour market (Dwyer and Mitchell 1999; Siegrist et al. 2006; Wahrendorf et al. 2013) and is strongly associated with nullifying the question of whether one is willing to work until official retirement age (Nilsson et al. 2011). Although some studies also indicate that financial incentives, such as generous early retirement benefits, increase the likelihood of early retirement, individuals seem to refrain from early retirement during prosperous economic periods (Stattin 2005). However, health problems remain a stronger predictor of retirement plans than economic variables (Dwyer and Mitchell 1999). Because the following analyses concentrate on two relatively young cohorts of the German baby boom (born in 1959 and 1965) - generations that are currently approximately 50 years of age - economic incentives are irrelevant. No financial incentives to withdraw from the labour market before age 60 exist in Germany. However, the lack of personal financial resources might reduce individuals' likelihood of withdrawing from employment for health reasons.

\section{Theoretical considerations}

Chirikos (1993, p. 297) argued that "poor health influences the willingness, as well as the capacity or ability, to perform job requirements" and described this relationship as a plausible mechanism linking health and actual changes in labour market participation. Peter and Hasselhorn (2013) further suggested that the immediate employment exit decision mediates part of the observed influence of health on labour market exit and that self-perceived work ability and work motivation influence the actual labour market behaviour. The authors argued that organisational structures and means might compensate for health impairments in such a way that even individuals with mental or physical impairments are able to perform paid work.

A few relevant theories can help explain the influence of health impairment on labour market participation, taking into account work motivation and self-perceived work ability. According to labelling theory based originally on Becker (1966), people with impaired health are labelled as outsiders in society, and their withdrawal from employment is commonly accepted or even expected. Impaired health is widely accepted as a reason for early labour market exit, and individuals with poor health are not expected to participate in the labour market. Because illness and incapacity are commonly understood to be closely related, individuals should reduce their perception of work ability and their motivation to work, instead of looking for compensatory measures or alternative employment opportunities.

Similarly, Goffman's (1963) theoretical work on stigma suggested that poor health might overshadow the personal identity granted by the employment status. The status of "being ill" becomes more prevalent than the social status of a worker or employee, and withdrawal from work is the logical consequence. Thus, poor health can reduce the 
motivation to work in favour of other aspects of life. In this sense, the perception of a negative difference (deviance) in health status or a shift of preferences rather than the actual health-related impairment leads to employment exit. Illness becomes a social role or what Parson (1975) called the "sick role", and a person is exempted from his or her usual roles by both others and themselves. In this sense, the "sick role" can function as an accepted excuse to exit from employment not only for individuals themselves but also the employers who might choose to release impaired employees rather than adopt compensatory measures in the workplace.

Finally, Williams (1984) argued that people in poor health attempt to find a reason for their health condition through a narrative reconstruction. For example, working conditions might be used as an explanation for health impairments and an excuse to exit from employment. In this sense, the social perception of health status becomes relevant. Men and women in occupations with high physical or psychological job demands are expected to sooner or later develop health impairments.

In sum, health is closely related to work motivation and self-perceived work ability. Impaired health and low work motivation or low self-perceived work ability might mutually influence the probability of labour market participation at advanced working age. Even when opportunities for compensation exist, impaired health can alter expectations of one's own ability to perform work and lead to a shift of preferences in life. Therefore, disentangling "the bundle of health capacities that influence the ability to perform market work [...] from the bundle that affect the preference for market work" (Chirikos 1993, p. 306) is necessary.

\section{Disentangling the complex interplay among health, work motivation, work ability and labour market exit}

Based on the previous studies reviewed and the theoretical considerations discussed, a few hypotheses can be formulated. First, the probability of labour market exit should increase when individuals report poor health. Second, the likelihood of withdrawal from employment should increase when individual work motivation is low or when individuals report low physical or mental work ability (c.f. Fig. 1).

However, the influences of health, work motivation and work ability should not be independent from one another. Rather, one might assume, third, that the perception of health through work ability and work motivation partly affects labour market exit (c.f. Fig. 2). In other words, work motivation and work ability can be assumed to partly mediate the relationship between health and labour market exit. In examining these mediational hypotheses, the effect of health on labour market exit must be divided into a direct and an indirect effect.

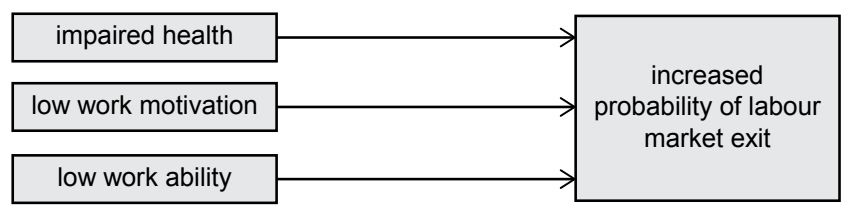

Fig. 1 Impaired health, low work motivation and low work ability and their influences on the likelihood of withdrawal from employment

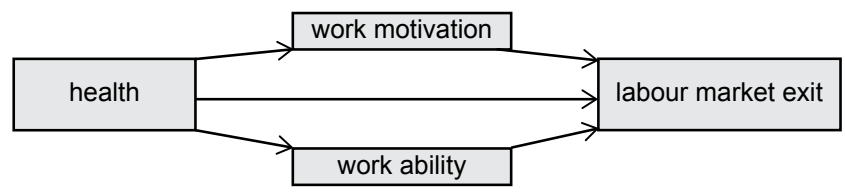

Fig. 2 Direct and indirect effects of health on the probability of early labour market exit

As noted above, health is related to both the ability to work and the motivation to work (Nilsson et al. 2011). Impaired health can lead to a decreased motivation to work, especially when work circumstances and particular tasks in the workplace further impair one's health. Although an individual might still be able to perform his or her former tasks, his or her work motivation might decrease and result in early labour market exit. Social acceptance of the "sick role" (Parson 1975) might further decrease work motivation and labour market withdrawal. Individuals with impaired health might develop different roles or patterns of identification apart from paid work, and the motivation to participate in the labour market might decrease.

Similarly, the perception of one's own work ability can decrease when health impairments occur despite potential compensating technical or organisational aids. Dependent on work tasks and requirements, an individual might not perceive enough work ability to continue working. The particular perception of one's own health impairment can become an obstacle to employment and decrease self-perceived work ability and encourage individuals to withdraw from employment.

Finally, and somehow in contrast to Peter and Hasselhorn (2013), it is assumed that health also has an strong independent (direct) effect on the likelihood of employment withdrawal, aside from work motivation and self-perceived work ability. Therefore, a direct effect should occur, especially with severely injured persons.

\section{Data and Methods}

\subsection{Data and sample}

To analyse the relationship among health, work ability and work motivation and their impacts on labour market withdrawal, the following analyses employ data from the first 
wave of the lidA Cohort Study (German Cohort Study on Work, Age, Health, and Work Participation) conducted in 2011. The survey data were linked to employment register data of the Federal Employment Agency to produce a one-year follow-up measurement of labour market status changes. The lidA data include a sample of 6,339 individuals born in 1959 and 1965 who were employed and subject to social insurance contributions at the time of the first interview in 2011.

The survey was designed to follow the ageing German baby boom generation and monitor their working conditions, attitudes towards work and individual health trajectories from the time they reach advanced working age until retirement. Compared with older cohorts, the baby boom cohorts not only are the most numerous but also have higher levels of education. However, their employment trajectories started later in their life span and are more heterogeneous, and the baby boomers experience more employment interruptions than the preceding cohorts (Tisch and Tophoven 2012). At the first interview, the respondents were at the threshold of advanced working age (i.e., 52 and 46 years old, respectively). Recent studies indicate that in Germany, deterioration of health, particularly due to chronic diseases and musculoskeletal limitations, begins after age 45 (Robert Koch-Institut 2012) and that both job changes and the ability to find employment decrease after age 50 (Dietz and Walwei 2011). Moreover, the likelihood of disability retirement increases rapidly after age 50 for men and age 46 for women (Hagen et al. 2010). At the same time, it can be assumed that the lidA birth cohorts were unable to make sufficient provisions for their retirement by the time of the interview. Hence, employment withdrawal is not likely driven by pullfactors of early retirement.

To follow the employment trajectories of the lidA respondents, the survey data were linked to employment register data. The linkage required written consent, which was granted by $78 \%$ of the respondents. After case-bycase exclusion of missing data on the main observables, 3,796 respondents were analysed. The respondents were employed at the time of the interview in 2011 and either remained employed with the same or another employer or withdrew from employment before 31st December 2012.

Approximately one year after the interview, most of the respondents were still employed (Table 1). Fifty-three had become unemployed, and 123 could no longer be found in the register data and most likely had left the labour market completely.

\subsection{Measures}

Labour market exit was measured by means of information from the employment register data of the Federal Employment Agency approximately one year after the baseline
Table 1 Labour market states at one-year follow-up lidA employees 31 December 2012:

in 2011:

\begin{tabular}{lccc}
\cline { 2 - 4 } & Employed & Unemployed & Out of the labour market \\
\hline 3,849 & 3673 & 53 & 123 \\
$100.0 \%$ & $95.4 \%$ & $1.4 \%$ & $3.2 \%$ \\
\hline
\end{tabular}

interviews (31 $1^{\text {st }}$ December 2012). Employed people were regarded as being on the labour market, and people with no information in the register data were regarded as having left the labour market. Men and women who were registered as unemployed received no consideration and were excluded from the analyses. In addition to the one-year followup measurement, the number of days until labour market exit until 31st December 2012 was regarded as a second outcome.

Individual health was measured by self-rated health status at the 2011 interview. The respondents were asked to rate their "current general health status" on a five-point scale: very good health, good health, satisfactory health, poor health and very poor health. The ordinal scale was used in the analyses. It has been argued that respondents might use different frames of reference to answer a single-item question on self-rated health (Krause and Jay 1994). However, findings have indicated that frames of reference mostly vary by age and that subjective health measurements are valid indicators in middle-aged populations that can best be used in cohort studies (Miilunpalo et al. 1997). The second variable of interest is self-perceived physical and mental work ability (Hasselhorn and Freude 2007). The lidA questionnaire contains the current self-rated work ability with respect to physical and mental work requirements. The respondents are asked to assess their mental and physical work ability ${ }^{2}$ on a five-point scale: very good, good, intermediate, rather poor and very poor work ability. The self-rated work ability indices in the lidA study are one dimension of the Work Ability Index originally established in Finland and tested in many multi-disciplinary and longitudinal studies (Ilmarinen and Tuomi 1993; Ilmarinen et al. 2005). The questions refer directly to the current work situation and the specific demands in the workplace.

Work motivation was measured by the individual intentions to exit employment ${ }^{3}$. The following analyses distinguish respondents who had considered exiting employment permanently at least several times within 12 months before

\footnotetext{
${ }^{2}$ Question A: How do you rate your current work ability with respect to the physical demands of your work?Question B: How do you rate your current work ability with respect to the mental demands of your work?

${ }^{3}$ Question: How often did you think about resigning from employment at all within the last twelve months? Answers: 1: never; 2: several times per year; 3: several times per month; 4: several times per week, 5: every day
} 
Table 2 Average marginal effects for labour market exit by self-rated health, work ability, and work motivation Dependent Variable: Employment Exit

\begin{tabular}{|c|c|c|c|c|c|c|c|c|}
\hline & \multirow{2}{*}{$\begin{array}{l}\text { Univariate } \\
\text { models }\end{array}$} & \multicolumn{4}{|c|}{ Including control variables } & \multicolumn{3}{|l|}{ Health and... } \\
\hline & & & & & & $\begin{array}{l}\text { Physical work } \\
\text { ability }\end{array}$ & $\begin{array}{l}\text { Mental work } \\
\text { ability }\end{array}$ & $\begin{array}{l}\text { Work } \\
\text { motivation }\end{array}$ \\
\hline $\begin{array}{l}\text { Subjective health status } \\
(1=\text { very good; } 5=\text { im- } \\
\text { paired health) }\end{array}$ & $\begin{array}{l}0.0096^{* *} \\
(0.003)\end{array}$ & $\begin{array}{l}0.0093 * * \\
(0.003)\end{array}$ & & & & $\begin{array}{l}0.0069+ \\
(0.004)\end{array}$ & $\begin{array}{l}0.0082^{*} \\
(0.004)\end{array}$ & $\begin{array}{l}0.0083^{*} \\
(0.003)\end{array}$ \\
\hline $\begin{array}{l}\text { Work ability (physical) } \\
(1=\text { very good; } 4=\text { bad })\end{array}$ & $\begin{array}{l}0.0092 * * \\
(0.003)\end{array}$ & & $\begin{array}{l}0.0089^{* *} \\
(0.003)\end{array}$ & & & $\begin{array}{l}0.0056 \\
(0.004)\end{array}$ & & \\
\hline $\begin{array}{l}\text { Work ability (mental) }(1= \\
\text { very good; } 4=\text { bad })\end{array}$ & $\begin{array}{l}0.0066^{*} \\
(0.003)\end{array}$ & & & $\begin{array}{l}0.0064^{*} \\
(0.003)\end{array}$ & & & $\begin{array}{l}0.0036 \\
(0.003)\end{array}$ & \\
\hline $\begin{array}{l}\text { Work motivation (prefer- } \\
\text { ence for exiting employ- } \\
\text { ment; ref: satisfied with } \\
\text { current work situation) }\end{array}$ & $\begin{array}{l}0.0195^{* *} \\
(0.008)\end{array}$ & & & & $\begin{array}{l}0.0193^{* *} \\
(0.008)\end{array}$ & & & $\begin{array}{l}0.0156^{*} \\
(0.008)\end{array}$ \\
\hline Female & & $\begin{array}{l}0.0061 \\
(0.006)\end{array}$ & $\begin{array}{l}0.0061 \\
(0.006)\end{array}$ & $\begin{array}{l}0.0061 \\
(0.006)\end{array}$ & $\begin{array}{l}0.0062 \\
(0.006)\end{array}$ & & & \\
\hline $\begin{array}{l}\text { Household income below } \\
\text { poverty line }\end{array}$ & & $\begin{array}{l}0.0109 \\
(0.011)\end{array}$ & $\begin{array}{l}0.0104 \\
(0.011)\end{array}$ & $\begin{array}{l}0.0116 \\
(0.011)\end{array}$ & $\begin{array}{l}0.0124 \\
(0.011)\end{array}$ & & & \\
\hline $\begin{array}{l}\text { No partner (ref.: partner } \\
\text { employed) }\end{array}$ & & $\begin{array}{l}-0.0028 \\
(0.007)\end{array}$ & $\begin{array}{l}-0.0030 \\
(0.007)\end{array}$ & $\begin{array}{l}-0.0027 \\
(0.007)\end{array}$ & $\begin{array}{l}-0.0020 \\
(0.007)\end{array}$ & & & \\
\hline $\begin{array}{l}\text { Partner not employed (ref: } \\
\text { partner employed) }\end{array}$ & & $\begin{array}{l}0.0046 \\
(0.010)\end{array}$ & $\begin{array}{l}0.0043 \\
(0.010)\end{array}$ & $\begin{array}{l}0.0048 \\
(0.010)\end{array}$ & $\begin{array}{l}0.0049 \\
(0.010)\end{array}$ & & & \\
\hline Observations & 3,796 & 3,796 & 3,796 & 3,796 & 3,796 & 3,796 & 3,796 & 3,796 \\
\hline Pseudo R-squared & & 0.010 & 0.009 & 0.006 & 0.008 & 0.009 & 0.009 & 0.011 \\
\hline
\end{tabular}

the interview from those satisfied with their current work situation.

Finally, a few covariates generated from the lidA survey are used in this study. Gender and financial circumstances (whether the respondent lives in a household below the Organization for Economic Cooperation and Development (OECD)-rated poverty line), as well as the partner's employment status (employed, not employed, no partner), serve as control variables. The variables of interest and the covariates are summarised in Appendix Table 4.

\subsection{Estimation approaches}

First, univariate logistic regression models are calculated to clarify the relationship among health, work motivation and work ability in labour market exit (c.f. Fig. 1). Health, work motivation and work ability are first tested as single predictors and second with additional control variables. Additional models consider the relationship between health and work ability and health and work motivation and employment exit. Furthermore, as a robustness check, proportional hazard models as proposed by Cox (1972) are calculated to analyse labour market exit rates.

In a second approach, the Karlson-Holm-Breen (KHB) method (Breen et al. 2013) is applied to deconstruct the effect of health into direct and indirect effects, considering work motivation and work ability as mediator variables (c.f.
Fig. 2). In linear regression models, decomposing the total effect into a direct and an indirect effect is straightforward. The difference between the estimated coefficients of the explanatory variable $\mathrm{X}$, between a "reduced model" and a "full model" including the mediator variable $\mathrm{Z}$, describes the indirect effect of $X$ through $Z$. Estimated coefficients in nonlinear regression models are not comparable between different models. The KHB method helps solve this problem and considers the difference of coefficients due to both confounding and rescaling of the model that occurs when the mediator variable has an independent effect on the dependent variable (Kohler et al. 2011, p. 421).

\section{Results}

Table 2 summarises the logistic regression models. The first column presents the univariate models and indicates that all variables of interest influence the likelihood of labour market exit: Impaired self-rated health increases the probability of labour market withdrawal. Additionally, low physical and mental work ability and low work motivation, described by the preference for exiting employment, seem to increase the probability of labour market withdrawal. The effects also remain significant after including the control variables (Table 2, columns 2-5). 
When considering health and work ability in the same model, the coefficients for work ability are statistically insignificant (Table 2, columns 6-7). Additionally, the statistical significance of the effect of work motivation diminishes when health is considered in the same model (Table 2, columns 8). Therefore, one might assume that the effect of health on the probability of labour market withdrawal overlaps with the effects of work ability and work motivation. The Cox-models reveal mostly similar results: The effect of health decreases when considering work ability and work motivation (c.f. Appendix Table 5).

Furthermore, the KHB method is applied to test to what extent labour market withdrawal is due to the perception of health and whether the perception of work ability and work motivation mediates the relationship between health and labour market exit. For this purpose, the effect of health on labour market exit was deconstructed into a direct and an indirect effect, considering work motivation and work abilities, respectively. Considering self-perceived health status as a dummy variable $(1=$ poor/very poor health; $0=$ satisfactory, good or very good health), we see that impaired health increases the log odds of employment exit by 0.027 (c.f. Table 3). Further controlling for low work motivation, the effect of impaired health decreases to 0.025 ; leaving an indirect effect of 0.002 . However, because the magnitude of logit coefficients is difficult to interpret, Table 3 also provides confounding percentages ${ }^{4}$ : approximately $8 \%$ of the total effect of health is due to low work motivation. Finally, Table 3 reveals that self-perceived physical and mental work ability explain approximately $3-8 \%$ of the effect of health on labour market withdrawal.

In sum, work motivation and self-perceived mental work ability only partly mediate the relationship between individual health and labour market exit. The mediating effect of physical work ability is on an even lower level.

\section{Discussion and Conclusion}

This article illuminates the interrelated influences of health, work ability and work motivation on actual labour market participation among German baby boomers currently reaching advanced working age. A one-year follow-up study is conducted to test the extent of health influences on labour market withdrawal. Additionally, multivariate models are applied to examine the mediational influences of self-perceived work ability and work motivation on the relationship between health and labour market exit. Work ability is measured by self-perceived mental and physical work ability, and work motivation describes individuals' considerations in exiting employment. This study defines labour market

$\left.\left.\overline{{ }^{4}\left(\left(\beta_{\text {reduced model }}-\right.\right.} \beta_{\text {full model }}\right) / \beta_{\text {reduced model }}\right) * 100$
Table 3 Decomposition of the effect of health on labour market withdrawal

\begin{tabular}{ll}
\hline & $\begin{array}{l}\text { Health } \\
\text { (dummy) }\end{array}$ \\
\hline Reduced model (without mediator variable) & $0.027^{* * *}$ \\
Full model (including work motivation) & $0.025^{* * *}$ \\
$\%$ of total effect & 7.94 \\
Reduced model (without mediator variable) & $0.028^{* * *}$ \\
Full model (including physical work ability) & $0.027^{* * *}$ \\
$\%$ of total effect & 3.13 \\
Reduced model (without mediator variable) & $0.027^{* * *}$ \\
Full model (including mental work ability) & $0.025^{* * *}$ \\
$\%$ of total effect & 8.18 \\
\hline$* * *, * *, *+$ indicate significance levels at $0.1,1,5$, and $10 \%$, \\
respectively.
\end{tabular}

exit as a transition from employment to non-employment within one year without receiving unemployment benefits.

The findings reveal an increased probability of labour market withdrawal within one year when individuals report health impairments, low physical or mental work ability or low work motivation (preferences for exiting employment). The analyses further indicate that low work motivation and poor work ability mediated part of the relationship between health and labour market exit after one year. Hence, part of the negative effect of impaired health on labour market participation can be explained by low work motivation and by low self-perceived work ability $(<10 \%)$. In other words, those who suffer from impaired health might also consider themselves not capable of work and show low motivation to participate in the labour market. The combination of impaired health and low work motivation increases the likelihood of withdrawal from employment.

The analyses indicate similar results to previous studies, namely that in addition to health (McDonough and Amick 2001; Cai 2010), low self-perceived work ability (Alavinia et al. 2009; Reiso et al. 2001) and intention to exit employment (low work motivation) (Örestig et al. 2013) predict labour market withdrawal. Furthermore, the findings shed light on the well-known association among "can work" attitudes, "want work" attitudes and health (Nilsson et al. 2011). The results show that the relationship between health and employment exit is partly mediated by work motivation and self-perceived work ability. However, one must note that the mediational effect is comparatively small and that the direct effect of health remains important. Therefore and in contrast to the theoretical model of Peter and Hasselhorn (2013), the results suggest that health still has an independent direct effect on the likelihood of employment withdrawal, aside from work motivation and self-perceived work ability. Hence, at approximately age 50, the perception of health remains a strong predictor of early labour market exit and can only partly be explained by low work ability and low work motivation. Further research should focus on 
the mediational effect. Perhaps a more detailed measurement of work motivation and work ability could explain more of the relationship between health and employment withdrawal.

Theoretical assumptions driven from social reconstruction theories can help explain the negative effect that poor health has on the probability that older workers will leave the labour market within one year. Therefore, low self-perceived work ability and low work motivation increase the likelihood of labour market withdrawal because of health impairments. Poor health is negatively associated with the anticipation of work ability, work motivation, and participation in the labour market. Self-identity and individual behaviour seem to be influenced by the status of being in poor health, and individuals with a poor health status seem to adopt inactivity as an acceptable role.

In addition to accepting the "sick role" (Parson 1975) as an explanation for why the association between health and labour market participation is mediated by low work ability and low work motivation, working conditions and organisational structure might push individuals with health impairments out of the labour market. Job demands are primarily responsible for poor health and lead to decreasing attachment to work and longer absences (Bakker et al. 2003). Moreover, impaired health, low work ability and a lack of clear preference for work may result from high job strain and work stress (Kivimäki et al. 2002). Increasing work intensity and working at high speed (Parent-Thirion et al. 2007) prospectively might result in reduced health, low work ability and weak work motivation of future older workers. Therefore, measures promoting individual health should be improved, and work should be organised ensuring recovery phases and prevention of work stress. In addition to occupational health measures, training and motivation programmes and measures targeting declining work ability could help improve labour market participation. These measures could also include training on compensating technical aids.

\subsection{Advantages and disadvantages of the study}

Advantages of the study include the distinctive survey questionnaire specifically designed to examine health- and workrelated factors. The specific cohort design of the study, which controls for age effects, and the opportunity to link survey data to prospective register data are further advantages of the study. The data linkage provides a unique opportunity to follow the survey participants even years after the interview. In particular, health status, the main predictor in this study, might cause refusal to participate in further survey rounds, and register data help to monitor employment behaviour.

However, two main disadvantages of the study design must be considered. First, health status is measured by self- rated health, and more objective measures are not available. Although subjective health measurements have been found to be valid indicators for morbidity and mortality (Miilunpalo et al. 1997; Idler and Benyamini 1997; Singh-Manoux et al. 2006), it would be interesting to identify what roles specific diagnoses such as cancer, apoplectic stroke or paraplegia play in labour market withdrawal. It might be assumed that the degree of mediation through work ability and work motivation depends on the diagnoses in question. Severe health problems and illnesses are also not included in the register data and therefore cannot be controlled in a longitudinal perspective.

A second disadvantage of the study concerns the measurement of employment exit. This study cannot control whether employment exit is temporary or permanent, and a longer follow-up becomes necessary when discussing employment exit in favour of (early) retirement. Additionally, the register data only allow distinguishing among employment, unemployment and periods without social security distributions. In this study, those who cannot be found in the register data are considered true outsiders who are neither receiving unemployment benefits nor currently seeking employment. Hypothetically, it is also possible that these men and women became self-employed or civil servants. A further follow-up until the official retirement age of the respondents appears helpful to examine the relationship between health and complete labour market withdrawal and will be possible in the future.

\subsection{Implications for further research}

Further research should disentangle the interrelated effects of health, work motivation and work ability on labour market withdrawal from a longitudinal perspective. The research should determine whether the negative effects of impaired health, low work motivation and low work ability on employment exit increase throughout employees' lives and how the associations among health, work motivation and work ability affect transitions into (early) retirement. Second, to apply age group-specific supporting programmes, determining whether health becomes more important in both the relationship between work motivation and labour market participation and the relationship between self-perceived work ability and labour market participation would be useful.

\section{Kurzfassung}

Derzeit sind rund $20 \%$ der jährlichen Rentenneuzugänge in Deutschland vorzeitige Renteneintritte aufgrund von Erwerbsunfähigkeit und damit auf gesundheitliche Einschränkungen zurückzuführen. Während älteren Geburts- 
kohorten noch unterschiedliche und häufig finanziell attraktive Möglichkeiten für einen vorzeitigen Erwerbsausstieg zur Verfügung standen, können die deutschen Babyboomerkohorten, als zukünftige Rentengeneration, den Arbeitsmarkt nur noch mit deutlichen Abschlägen und/ oder durch die Inanspruchnahme von Renten wegen verminderter Erwerbsfähigkeit vorzeitig verlassen. Von den zukünftigen Rentengenerationen wird erwartet, dass sie dem Arbeitsmarkt deutlich länger zur Verfügung stehen als bisherige Generationen. So sind die in diesem Beitrag untersuchten Geburtskohorten des deutschen Babybooms (1959 und 1965 Geborene) direkt von der Erhöhung des gesetzlichen Renteneintrittsalters betroffen. Das Renteneintrittsalter für die 1959 Geborenen beträgt 66 Jahre und 2 Monate, das der 1965 Geborenen dann 67 Jahre.

Gleichzeitig lässt sich beobachten, dass die Menschen immer älter werden und dabei auch mehr gesunde Lebensjahre gewinnen. Der immer besser werdende Arbeitsschutzvor allem im Hinblick auf körperliche Gefahren von Arbeit hat in den vergangenen Jahrzehnten zu deutlich weniger Arbeitsunfällen geführt und konnte die Prävention für bestimmte Berufskrankheiten nachhaltig verbessern. Vor diesem Hintergrund wird diskutiert, inwiefern Gesundheit zukünftig nur noch eine mittelbare Einflussgröße für den Erwerbsausstieg darstellt. Angenommen wird, dass der gesundheitsbedingte Erwerbsaustritt als Prozess zu verstehen ist und Personen mit gesundheitlichen Problemen zunächst anstreben die eigene Arbeitsfähigkeit zu erhalten, indem sie versuchen Arbeitsanforderungen und eigene Ressourcen in Einklang zu bringen. Gelingt dies nicht - so die Annahme - sinkt zunächst die Arbeitsmotivation der Betroffenen. Erst in der Folge kommt es zur Aufgabe der Erwerbstätigkeit. Damit sollte Erwerbsteilhabe durch die Einschätzung der eigenen Arbeitsfähigkeit sowie durch Arbeitsmotivation erklärt werden, aber nur indirekt durch den Gesundheitszustand.

Der vorliegende Beitrag prüft diese theoretischen Überlegungen empirisch und stellt die Frage, inwiefern selbsteingeschätzte Arbeitsfähigkeit und individuelle Arbeitsmotivation als Mediatoren für den Zusammenhang zwischen Gesundheit und Erwerbsausstieg gelten können. Die Studie stützt sich auf Daten der lidA-Studie, eine deutsche Kohortenstudie zu Arbeit, Alter, Gesundheit und Erwerbsteilhabe. Die lidA-Studie umfasst zwei Kohorten der Babyboomerjahrgänge: Erwerbstätige, die 1959 und 1965 geboren sind. Während beide Kohorten zu Beginn ihres Erwerbslebens durchschnittlich häufiger instabile Beschäftigungsverhältnisse aufzeigen als ältere Geburtskohorten, sind sie zum Betrachtungszeitpunkt und damit in der Mitte ihres Erwerbslebens vergleichsweise gut in den Arbeitsmarkt integriert. Im Rahmen der lidA-Studie werden nicht nur Gesundheitsindikatoren erhoben sondern auch Skalen zur Messung von Arbeitsfähigkeit und Arbeits- motivation. Zum Zeitpunkt der Befragung waren alle in der der vorliegenden Untersuchung berücksichtigten Personen erwerbstätig $(n=3.796)$. Um ihre weitere Erwerbsbeteiligung nachzuvollziehen, werden die lidA-Befragungsdaten mit Registerdaten der Bundesagentur für Arbeit (BA) verknüpft. Die Registerdaten speisen sich einerseits aus den Meldungen zur Sozialversicherung und andererseits aus Daten die im Beratungs- und Vermittlungsprozess der BA erhoben werden. Sie beinhalten tagesgenaue Informationen $\mathrm{zu}$ Zeiten sozialversicherungspflichtiger Beschäftigung, Arbeitslosigkeit, Arbeitssuche und zum Leistungsbezug im Rahmen des SGB II und SGB III. Die lidA-Befragung hat im Frühjahr/Sommer 2011 stattgefunden. In diesem Beitrag werden die lidA-Daten mit Registerdaten bis Ende 2012 verknüpft. So lässt sich nachvollziehen, welche Wechsel im Erwerbsstatus die lidA-Befragten innerhalb etwa eines Jahres vollzogen haben.

Die Ergebnisse der empirischen Analysen bestätigen zunächst, dass Personen mit gesundheitlichen Beeinträchtigungen, niedrigerer körperlicher oder geistiger Arbeitsfähigkeit sowie Personen welchen eine geringe Arbeitsmotivation zugeschrieben werden kann, eine erhöhte Wahrscheinlichkeit haben aus der aktuellen Beschäftigung auszuscheiden. Bei gleichzeitiger Berücksichtigung dieser drei Einflussgrößen zeigt sich weiterhin, dass sowohl Arbeitsmotivation als auch Arbeitsfähigkeit den Zusammenhang zwischen Gesundheit und Erwerbsausstieg beeinflussen. Um zu prüfen, inwiefern es sich hierbei um eine Mediation handelt, also inwiefern der Einfluss der Gesundheit durch Arbeitsfähigkeit und Arbeitsmotivation vermittelt wird, kommt die Karlson-Holm-Breen Methode der Dekomposition zur Anwendung. Hierbei zeigt sich, dass Arbeitsmotivation und Selbsteinschätzung der Arbeitsfähigkeit die Beziehung zwischen Gesundheit und Arbeitsmarktrückzug nur teilweise zu vermitteln vermögen $(<10 \%)$. Der selbsteingeschätzte Gesundheitszustand sollte also auch weiterhin und ungeachtet weiterer Einflüsse wie der Arbeitsfähigkeit und der Arbeitsmotivation als ein Prädiktor für vorzeitiges Ausscheiden aus dem Erwerbsleben gelten. Ein betriebliches Gesundheitsmanagement sollte demnach stets Maßnahmen zur Förderung der Gesundheit älterwerdender Erwerbstätiger berücksichtigen. Darüber hinaus wäre es für die langfristige Integration älterwerdender Belegschaften erstrebenswert auch Maßnahmen zur Förderung und zum Erhalt der individuellen Arbeitsfähigkeit und Arbeitsmotivation auszubauen.

Einschränkend ist anzumerken, dass der Gesundheitszustand in dieser Studie lediglich über die Selbsteinschätzung abgebildet wird. So können keine Aussagen über die Folgen bestimmter, eventuell schwerwiegender Diagnosen oder plötzlich auftretender Krankheiten, wie beispielsweise eines Herzinfarktes oder einer Krebserkrankung getroffen werden. Hierzu wären tiefergehende 
Analysen nötig. Außerdem werden nur Erwerbsaustritte innerhalb eines Jahres nach der Befragung berücksichtigt. $\mathrm{Ob}$ und unter welchen Bedingungen Personen wieder auf den Arbeitsmarkt zurückkehren, muss in weiterführenden Längsschnittstudien näher betrachtet werden.
Acknowledgements I am grateful to my colleagues from the lidAproject and to my fellow $\mathrm{PhD}$ candidates at the University of Bamberg for fruitful discussions of the issues examined in this article. I would also like to thank two anonymous reviewers for their helpful advices.

\section{Appendix}

Table 4 Sample descriptors

\begin{tabular}{lll}
\hline & Employed at $\mathrm{t}+1$ & Withdrawal from employment at $\mathrm{t}+1$ \\
\hline Poor or very poor health & $11.76 \%$ & $24.39 \%$ \\
Low work ability (physical) & $3.02 \%$ & $5.69 \%$ \\
Low work ability (mental) & $5.99 \%$ & $11.38 \%$ \\
Preference for exiting employment & $10.97 \%$ & $18.70 \%$ \\
Female & $49.44 \%$ & $54.47 \%$ \\
Household income below poverty line & $5.45 \%$ & $8.13 \%$ \\
Partner not employed & $11.71 \%$ & $13.82 \%$ \\
Observations & 3673 & 123 \\
\hline
\end{tabular}

Table 5 Cox proportional hazard model for labour market exit by self-rated health, work ability, and work motivation

\begin{tabular}{|c|c|c|c|c|c|c|c|c|}
\hline & \multirow{2}{*}{$\begin{array}{l}\text { Univariate } \\
\text { models }\end{array}$} & \multicolumn{4}{|c|}{ Including control variables } & \multicolumn{3}{|l|}{ Health and... } \\
\hline & & & & & & $\begin{array}{l}\text { Physical } \\
\text { work ability }\end{array}$ & $\begin{array}{l}\text { Mental work } \\
\text { ability }\end{array}$ & $\begin{array}{l}\text { Work } \\
\text { motivation }\end{array}$ \\
\hline $\begin{array}{l}\text { Subjective health status } \\
(1=\text { very good; } 5=\text { impaired } \\
\text { health })\end{array}$ & $\begin{array}{l}0.2742^{*} \\
(0.126)\end{array}$ & $\begin{array}{l}0.2792^{*} \\
(0.126)\end{array}$ & & & & $\begin{array}{l}0.1552 \\
(0.146)\end{array}$ & $\begin{array}{l}0.1818 \\
(0.136)\end{array}$ & $\begin{array}{l}0.2252+ \\
(0.128)\end{array}$ \\
\hline $\begin{array}{l}\text { Work ability (physical) } \\
(1=\text { very good; } 4=\text { bad })\end{array}$ & $\begin{array}{l}0.3239^{*} \\
(0.127)\end{array}$ & & $\begin{array}{l}0.3334 * * \\
(0.127)\end{array}$ & & & $\begin{array}{l}0.2427 \\
(0.148)\end{array}$ & & \\
\hline $\begin{array}{l}\text { Work ability (mental) } \\
(1=\text { very good; } 4=\text { bad })\end{array}$ & $\begin{array}{l}0.3028^{*} \\
(0.120)\end{array}$ & & & $\begin{array}{l}0.3083^{* *} \\
(0.120)\end{array}$ & & & $\begin{array}{l}0.2361+ \\
(0.130)\end{array}$ & \\
\hline $\begin{array}{l}\text { Work motivation }(1=\text { prefer- } \\
\text { ence for exiting employment })\end{array}$ & $\begin{array}{l}0.6912^{*} \\
(0.271)\end{array}$ & & & & $\begin{array}{l}0.6890^{*} \\
(0.271)\end{array}$ & & & $\begin{array}{l}0.5862 * \\
(0.278)\end{array}$ \\
\hline Female & & $\begin{array}{l}0.2736 \\
(0.220)\end{array}$ & $\begin{array}{l}0.2678 \\
(0.220)\end{array}$ & $\begin{array}{l}0.2621 \\
(0.220)\end{array}$ & $\begin{array}{l}0.2788 \\
(0.220)\end{array}$ & & & \\
\hline $\begin{array}{l}\text { Household income below } \\
\text { poverty line }\end{array}$ & & $\begin{array}{l}0.5776 \\
(0.403)\end{array}$ & $\begin{array}{l}0.5473 \\
(0.404)\end{array}$ & $\begin{array}{l}0.5811 \\
(0.403)\end{array}$ & $\begin{array}{l}0.6100 \\
(0.402)\end{array}$ & & & \\
\hline $\begin{array}{l}\text { No partner (ref.: partner } \\
\text { employed) }\end{array}$ & & $\begin{array}{l}-0.6245^{*} \\
(0.308)\end{array}$ & $\begin{array}{l}-0.6393^{*} \\
(0.3077)\end{array}$ & $\begin{array}{l}-0.6321 * \\
(0.308)\end{array}$ & $\begin{array}{l}-0.5987 \\
+(0.308)\end{array}$ & & & \\
\hline $\begin{array}{l}\text { Partner not employed (ref: } \\
\text { partner employed) }\end{array}$ & & $\begin{array}{l}-0.7476 \\
+(0.433)\end{array}$ & $\begin{array}{l}-0.7661 \\
+(0.433)\end{array}$ & $\begin{array}{l}0.7502^{*} \\
(0.433)\end{array}$ & $\begin{array}{l}0.7365+ \\
(0.432)\end{array}$ & & & \\
\hline Observations & 3796 & 3796 & 3796 & 3796 & 3796 & 3796 & 3796 & 3796 \\
\hline
\end{tabular}




\section{Literature}

Alavinia, S., Burdorf, A.: Unemployment and retirement and illhealth: a cross-sectional analysis across European countries. Int. Arch. Occup. Environ. Health. 82(1), 39-45 (2008). doi:10.1007/ s00420-008-0304-6

Alavinia, S., van den Berg, T., van Duivenbooden, C., Elders, L., Burdorf, A.: Impact of work-related factors, lifestyle, and work ability on sickness absence among Dutch construction workers. Scand. J. Work. Environ. Health. 35(5), 325-333 (2009)

Alavinia, S.M., van Duivenbooden, C., Burdorf, A.: Influence of work-related factors and individual characteristics on work ability among Dutch construction workers. Scand. J. Work. Environ. Health. 33(5), 351-357 (2007)

Annesley, C.: Lisbon and social Europe: towards a European 'adult worker model' welfare system. J. Eur. Social. Policy. 17(3), 195205 (2007)

Avendano, M., Mackenbach, J.P.: Life-course health and labour market exit in thirteen European countries: Results from SHARELIFE. In: MEA Discussion Papers 227-2010. Mannheim Research Institute for Economics of Aging, Mannheim, (2010)

Bakker, A.B., Demerouti, E., de Boer, E., Schaufeli, W.B.: Job demands and job resources as predictors of absence duration and frequency. J. Vocat. Behav. 62(2), 341-356 (2003). doi:http://dx.doi. org/10.1016/S0001-8791(02)00030-1

Becker, H.: Outsiders. Simon \& Schuster, New York (1966)

Bound, J., Schoenbaum, M., Stinebrickner, T.R., Waidmann, T.: The dynamic effects of health on the labor force transition of older workers. Labour. Econ. 6, 179-202 (1999)

Breen, R., Karlson, K.B., Holm, A.: Total, direct, and indirect effects in logit and probit models. Sociol. Methods. Res. 42(2), 164-191 (2013)

Buchholz, S., Rinklake, A., Blossfeld, H.-P.: Reversing early retirement in Germany. A longitudinal analysis of the effects of recent pension reforms on the timing of the transition to retirement and on pension incomes. Comp. Popul. Stud. (Zeitschrift für Bevölkerungswissenschaft) (2013)

Cai, L.: The relationship between health and labour force participation: Evidence from a panel data simultaneous equation model. Labour. Econ. 17, 77-90 (2010). doi:10.1016/j.labeco.2009.04.001

Cai, L., Kalb, G.: Health status and labour force participation: evidence from Australia. Health. Econ. 15, 241-261 (2006). doi:10.1002/ hec. 1053

Cardano, M., Costa, G., Demaria, M.: Social mobility and health in the Turin longitudinal study. Social. Sci. Med. 58, 1563-1574 (2004). doi:10.1016/S0277-9536(03)00354-X

Chirikos, T.N.: The relationship health an labour market status. Ann. Rev. Public. Health. 14, 293-312 (1993)

Cox, D.R.: Regression models and life-tables. J. R. Stat. Soc. Ser. B. 34(2), 187-220 (1972)

Deutsche Rentenversicherung: Rentenversicherung in Zeitreihen. DRV-Schriften Band 22, Berlin (2013)

Dietz, M., Walwei, U.: No country for old workers? J. Labour. Mark. Res. 44, 363-376 (2011)

Disney, R., Emmerson, C., Wakefield, M.: Ill health and retirement in Britain: A panel data-based analysis. J. Health. Econ. 25(4), 621-649 (2006)

Dwyer, D.S., Mitchell, O.S.: Health problems as determinants of retirement: Are self-rated measures endogenous? J. Health. Econ. 18 (1999)

Ebbinghaus, B., Hofäcker, D.: Reversing early retirement in advanced welfare economies. A paradigm shift to overcome push and pull factors. Comp. Popul. Stud. 38(4), 807-840 (2013)
Elstad, J.I., Krokstad, S.: Social causation, health-selective mobility, and the reproduction of socioeconomic health inequalities over time. Social. Sci. Med. 57(8), 1475-1489 (2003)

Fasang, A.E.: Retirement: Institutional pathways and individual trajectories in Britain and Germany. Sociol. Res. Online. 15(2) (2010)

Gamperiene, M., Nygard, J.F., Sandanger, I., Lau, B., Bruusgaards, D.: Self-reported work ability of Norwegian women in relation to physical and mental health, and to the work environment. J. Occup. Med. Toxicol. 3(8), 1-9 (2008)

Garcia-Gomez, P., Jones, A.M., Rice, N.: Health effects on labour market exits and entries. Labour. Econ. 17, 62-76 (2010). doi:10.1016/j.labeco.2009.04.004

Goffman, E.: Stigma. Notes on the Management of Spoiled Identity. Prentice-Hall, Englewood Cliffs (1963)

Hagen, C., Himmelreicher, R.K., Kemptner, D., Lampert, T.: Soziale Ungleichheit und Erwerbsminderungsrente. DRV-Schriften. 55, 86-102 (2010)

Harkonmäki, K., Lahelma, E., Martikainen, P., Rahkonen, O., Silventoinen, K.: Mental health functioning (SF-36) and intentions to retire early among ageing municipal employees: The Helsinki Health Study. Scand. J. Public. Health. 34(2), 190-198 (2006)

Hasselhorn, H.M., Freude, G.: Der Work Ability Index — ein Leitfaden. Verlag für neue Wissenschaft GmbH, Dortmund (2007)

Henkens, K., Tazelaar, F.: Early retirements of civil servants in the Netherlands. J. Appl. Social. Psychol. 24(21), 1927-1943 (1994)

Heponiemi, T.: Health, psychosocial factors and retirement intentions amon Finish physicians. Occup. Med. 58(6), 406-412 (2008)

Higgs, P., Mein, G., Ferrie, J., Hyde, M., Nazroo, J.: Pathways to early retirement: structure and agency in decision-making among British civil servants. Ageing. Soc. 23(06), 761-778 (2003). doi:10.1017/ S0144686X03001326

Hopsu, L., Leppänen, A., Ranta, R., Louhevaara, V.: Perceived work ability and individual characteristics as predictors for ealy exit from working life in professional cleaners. Int. Congr. Ser. 1280(1), 84-88 (2005)

Houston, D., Lindsay, C.: Fit for purpose? Lessons for policies to address the disability benefits 'Crisis'. In: Lindsay, C., Houston, D. (eds.) Disability Benefits, Welfare Reform and Employment Policy, pp. 233-241. Palgrave Macmillan, Hampshire (2013)

Idler, E.L., Benyamini, Y.: Self-rated health and mortality: A review of twenty-seven community studies. J. Health. Social. Behav. 38(1), 21-37 (1997). doi:10.2307/2955359

Ilmarinen, J.: Ageing Workers in the European Union-Status and Promotion Of Work Ability, Employability and Employment. Finnish Institute of Occupational Health, Helsinki (1999)

Ilmarinen, J.: Aging workers. Occup. Environ. Med. 58, 546-552 (2001)

Ilmarinen, J., Tuomi, K.: Work ability index for aging workers. In: Ilmarinen, J. (ed.) Aging and Work, Proceedings 4. Institute of Occupational Health, Helsinki, (1993)

Ilmarinen, J., Tuomi, K., Seitsamo, J.: New dimensions of work ability. Int. Congr. Ser. 1280, 3-7 (2005). doi:http://dx.doi.org/10.1016/j. ics.2005.02.060

Kivimäki, M., Leino-Arjas, P., Luukkonen, R., Riihimäki, H., Vahtera, J., Kirjonen, J.: Work stress and risk of cardiovascular mortality: prospective cohort study of industrial employees. Br. Med. J. 325(857), 1-5 (2002)

Kohler, U., Karlson, K.B., Holm, A.: Comparing coefficients of nested nonlinear probability models. Stata. J. 11(3), 420-438 (2011)

Krause, N.M., Jay, G.M.: What do global self-rated health items measure? Med. Care. 32(9), 930-942 (1994)

Maurer, J., Klein, R., Vella, F.: Subjective health assessments and acrive labor market participation of older men: Evidence from a semiparametric binary choice model with nonadditive correlated individual-specific effects. Rev. Econ. Stat. 93(3), 764-774 (2011) 
McDonough, P., Amick, B.C.: The social context of health selection: a longitudinal study of health and employment. Social. Sci. Med. 53, 135-145 (2001)

Miilunpalo, S., Vuori, I., Oja, P., Pasanen, M., Urponen, H.: Selfrated health status as a health measure: The predictive value of self-reported health status on the use of physician services and on mortality in the working-age population. J. Clin. Epidemiol. 50(5), 517-528 (1997). doi:http://dx.doi.org/10.1016/ S0895-4356(97)00045-0

Nilsson, K., Rignell Hydbom, A., Rylander, L.: Factors influencing the decision to extend working life or retire. Scand. J. Work. Environ. Health. 37(6), 473-480 (2011). doi:10.5271/sjweh.3181

Örestig, J., Strandh, M., Stattin, M.: A wish come true? A longitudinal analysis of the relationship between retirement preferences and the timing of retirement. Popul. Ageing. 6(1-2), 99-118 (2013). doi:10.1007/s12062-012-9075-7

Parent-Thirion, A., Macías, E.F., Hurley, J., Vermeylen, G.: Fourth European Working Conditions Survey., vol. Eurofound. Publications Office of the European Union, Luxembourg (2007)

Parson, T.: The sick role and the role of the physician reconsidered. Milbank. Mem. Fund. Q. Health. Soc. 53(3), 257-278 (1975)

Peter, R., Hasselhorn, H.M.: Work, age, health, and work participation. A theoretical model. Bundesgesundheitsblatt. 56(3), 415-421 (2013). doi:10.1007/s00103-012-1615-z

Prothero, J., Beach, L.R.: Retirement decisions: Expectation, intention, and action. J. Appl. Social. Psychol. 14(2), 162-174 (1984)

Reiso, H., Nygård, J.F., Brage, S., Gulbrandsen, P., Tellnes, G.: Work ability and duration of certified sickness absence. Scand. J. Public. Health. 29(3), 218-225 (2001). doi:10.1177/14034948010290031 201

Robert Koch-Institut (Ed.) Daten und Fakten: Ergebnisse derStudie „Gesundheit in Deutschland aktuell 2010“. Beiträge zur Gesundheitsberichterstattung des Bundes. RKI, Berlin(2012)

Schuring, M., Burdorf, L., Kunst, A., Mackenbach, J.: The effects of ill health on entering and maintaining paid employment. Evidence in European countries. J. Epidemiol. Community. Health. 61, 597-604 (2007)

Sell, L.: Predicting long-term sickness absence and early retirement pension from self-reported work ability. Int. Arch. Occup. Environ. Health. 82(9), 1133-1138 (2009). doi:10.1007/ s00420-009-0417-6

Siegrist, J., Wahrendorf, M., von dem Knesebeck, O., Jürges, H., Börsch-Supan, A.: Quality of work, well-being, and intended early retirement of older employees - baseline results from the SHARE Study. Eur. J. Public. Health. 17(1), 62-68 (2006). doi:10.1093/ eurpub/ck1084

Singh-Manoux, A., Martikainen, P., Ferrie, J., Zins, M., Marmot, M., Goldberg, M.: What does self rated health measure? Results from the British Whitehall II and French Gazel cohort studies. J Epidemiol. Community. Health. 60(4), 364-372 (2006)

Sörensen, L.: Work Ability and Health-Related Quality of Life in Middle-Aged Men. The Role of Physical Activity and Fitness. Faculty of Medicine of the University of Kuopio, Kuopio, Finland (2008)
Stattin, M.: Retirement on grounds of ill health. Occup. Environ. Med. 62(2), 135-140 (2005)

Suadicani, P., Bonde, J.P., Olesen, K., Gyntelberg, F.: Job satisfaction and intention to quit the job. Occup. Med. 63(2), 96-102 (2013). doi:10.1093/occmed/kqs233

Taylor, M.A., Shore, L.M.: Predictors of planned retirement age: An application of Beehr's model. Psychol. Aging. 10, 76-83 (1995)

Tisch, A., Tophoven, S.: Employment biographies of the German Baby Boomer Generation. Schmollers. Jahrb. 132(2), 205-232 (2012) (Zeitschrift für Wirtschafts- und Sozialwissenschaften)

Topa, G., Moriano, J.A., Depolo, M., Alcover, C.-M., Morales, J.F.: Antecedents and consequences of retirement planning and decision-making: A meta-analysis and model. J. Vocat. Behav. 75, 38-55 (2009)

Tuomi, K., Huuhtanen, P., Nykyri, E., Ilmarinen, J.: Promotion of work ability, the quality of work and retirement. Occup. Med. 51(5), 318-324 (2001)

van Dam, K., van der Vorst, J.D.M., van der Heijden, B.I.J.M.: Employees' intentions to retire early: A case of planned behavior and anticipated work conditions. J. Career. Dev. 35(3), 265-289 (2009). doi:10.1177/0894845308327274

van de Mheen, H., Stronks, K., Schrijvers, C., Mackenbach, J.: The influence of adult ill health on occupational class mobility out of and into employment in The Netherlands. Soc. Sci. Med. 49, 509-518 (1999)

van den Berg, T., Alavinia, S.M., Bredt, F., Lindeboom, D., Elders, L., Burdorf, A.: The influence of psychosocial factors at work and life style on health and work ability among professional workers. Int. Arch. Occup. Environ. Health 81(8), 1029-1036 (2008)

van den Berg, T., Elders, L., Burdorf, A.: Influence of health and work on early retirement. J. Occup. Environ. Med. 52(6), 576-583 (2010a)

van den Berg, T., Schuring, M., Avendano, M., Mackenbach, J., Burdorf, A.: The impact of ill health on exits from paid employment in Europe among older workers. Occup. Environ. Med. 67, 845-852 (2010b). doi:10.1136/oem.2009-051730

Wahrendorf, M., Dragano, N., Siegrist, J.: Social position, work stress, and retirement intentions: A study with older employees from 11 European countries. Eur. Sociol. Rev. 29(4), 792-802 (2013). doi:10.1093/esr/jcs058

Williams, G.: The genesis of chronic illness: narrative re-construction. Sociol. Health. Illn. 6(2), 175-200 (1984)

Anita Tisch, studied sociology at the University of Bamberg (diploma) and earned a M.Sc. in Gerontology at the University of Southampton. Since 2009 she is working at the Institute for Employment Research (IAB) as a researcher. Her main research interests are the ageing work force, politics of employability and labour market and health. 